\title{
Design and Implementation of Project-oriented and Task-driven Teaching Model_-Take Logistics Strategy Consulting as an example
}

\author{
Rongcheng Qu* \\ Shihezi University, Shihezi 832000, Xinjiang, China. \\ E-mail: 7113891@qq.com
}

\begin{abstract}
The course Logistics Strategy Consulting has the characteristics of strong practicality, strong comprehensiveness and emphasis on analytical thinking. The traditional classroom teaching model has been difficult to adapt to the teaching requirements of this course. At the same time, in the context of higher education reform, a new "project-oriented, task-driven" teaching model came into being. The implementation of the logistics strategy consulting course based on the new teaching model can effectively improve the practicality of course teaching and stimulate students' comprehensive analysis ability to achieve higher teaching quality. In this regard, the following article discusses the design and implementation of the "project-oriented, task-driven" teaching mode of the "Logistics Strategy Consulting" course, in order to lay a good foundation for the further promotion and application of this teaching model.
\end{abstract}

Keywords: Project-oriented; Task-driven; Teaching Model; Design and Implementation

Logistics Strategy Consulting is one of the basic courses for logistics majors in colleges and universities. It requires the training of not only rich logistics professional knowledge, but also strong logistics practical application capabilities, as well as high skills in the professionalism of logistics strategic innovation awareness for high-quality logistics talents. The new project-oriented, task-driven teaching model can effectively establish a new student-based teaching model, and can formulate teaching tasks and develop teaching project design according to the actual conditions of students. The current project-oriented, task-driven teaching model design requires the integration of two teaching methods of the project-oriented teaching method and the task-driven teaching method. At the same time, the teaching practice activities are carried out in accordance with the characteristics of the logistics strategy consulting course. The specific teaching mode design and implementation are presented as the following aspects.

\section{Based on project-oriented, task-driven teaching model design concepts and ideas}

\subsection{Design concept}

First, formulate a new talent training model. To achieve the project-oriented and task-driven teaching model reform of the Logistics Strategic Consulting course, it is necessary to re-determine talent training goals and build a new talent training model. This requires the course to be able to utilize the development of school-based teaching resources and provide technical services based on the training of the "professional+project" professional construction model, the school-enterprise cooperation platform, and the training base inside and outside the school. Realize the talent training model of school-enterprise cooperation and combination of work and study.

Second, build a two-way teaching model with students as the main body and teachers as guidance. In the project-oriented, task-driven teaching model, it is required to be able to stimulate students' interest in learning based on the individual development of students in a variety of teaching methods, so that students can actively participate in the in-depth exploration and learning of the Logistics Strategy Consulting course. Only then can it is possible to launch deep learn-

Copyright ( 2020 Rongcheng Qu

doi: 10.18282/le.v9i6.1351

This is an open-access article distributed under the terms of the Creative Commons Attribution Non-Commercial License

(http://creativecommons.org/licenses/by-nc/4.0/), which permits unrestricted non-commercial use, distribution, and reproduction in any medium, provided the original work is properly cited. 
ing and improve students' practical application ability of logistics strategy.

\subsection{Design ideas}

First, build a project-oriented curriculum structure. In the Logistics Strategy Consulting course, it is necessary to train students' logistics-related skills as the core, and use real project activities to reconstruct the teaching content, so that the Logistics Strategy Consulting course can realize the development of theory and practice.

Second, adopt a task-driven teaching model. Develop a new teaching model that is task-driven, case-based teaching, and the integration of theory and practice, so that the teaching, practice and evaluation of the Logistics Strategy Consulting course can be integrated.

\section{Design of teaching system based on the project-oriented and task-driven teaching model}

\subsection{Teaching content design}

First, realize the design of course teaching content. In the traditional Logistics Strategy Consulting course teaching, it is mainly to teach the content of the textbook according to the text, which directly leads to the students' low practical application ability, low interest in theoretical knowledge learning, and weak market adaptability in the future. For this, when the logistics major of the school launches the course teaching, it can conduct multi-party investigations to master the quality and ability requirements of the market talents of the subject. Thereby reconstructing the content of the course. The course Logistics Strategy Consulting includes the basic theoretical functions of logistics; innovative logistics practices and systems, and implementation of logistics systems. According to market surveys, innovative logistics practices and systems and implementation of logistics systems are the cores. Therefore, teachers can use specific logistics system cases to carry out logistics and supply chain information system teaching, so that students can clearly grasp the advantages and disadvantages of the current logistics information system selection and implementation based on market development needs, to realize the optimization and innovation of the logistics information system.

Second, the arrangement of course teaching content. Under normal circumstances, the course Logistics Strategy Consulting in major universities is arranged for one semester, usually about 40 class hours. The teaching content of the course presents the characteristics of tight time and heavy tasks. Therefore, in the project-oriented, task-driven teaching model, it is necessary to realize the task decomposition of each teaching project, from simple to difficult, put multiple teaching tasks in one teaching project, so as to design independent but interrelated teaching task. For example, the Logistics Strategy Consulting course can be launched in four steps: classroom guidance training, classroom operation demonstration, classroom synchronization training, and extracurricular outreach training, which can greatly improve the efficiency and quality of classroom teaching.

\subsection{Teaching method design}

First, the design of classroom teaching organization. When teaching the course Logistics Strategy Consulting, after determining the teaching content and teaching plan, it is required to adopt brand-new teaching methods and teaching organization methods to ensure that students' interest in learning can be stimulated and students' learning innovation and creativity can be mobilized. Therefore, when designing teaching methods, on the one hand, it is required to be based on the principle of diversification, that is, different teaching methods must be adopted under different teaching steps in order to motivate the students to learn and explore and develop teaching practice applications. On the other hand, they need also to pay attention to the combination of practice and theory. Logistics Strategy Consulting is a highly comprehensive subject, which requires students to master a wealth of logistics analysis methods, have practical exploration capabilities, and be able to better respond to market job demands. At present, the theoretical knowledge and practical activities of logistics information analysis cannot be isolated from each other in teaching, resulting in low comprehensive quality of students. In the project-oriented, task-driven teaching mode, a teaching model integrating theory and practice can be constructed. That is, in classroom teaching, actual logistics cases can be used as carriers, knowledge can be introduced into actual cases, and students can be guided to imitate and demonstrate operations, thereby enhancing students' logistics information system analysis and practical capabilities. It is also possible to gradually strengthen students' lo- 
gistics information analysis and practical ability through the framework of stepped skill training.

Second, the design of diversified methods for classroom teaching. With the development of education informatization, more and more novel teaching methods are entering classroom teaching activities. Under the current project-oriented, task-driven teaching model, it is required to be able to comprehensively apply a variety of teaching methods, enhance students' interest in participating in learning, and stimulate students' motivation to carry out inquiry and analysis. For example, in the teaching of the principle and system of customer response, the customer response performance measurement is required, which requires the introduction of case analysis to provide students with real logistics customer response data, so that students can use specific analysis methods to analyze customer satisfaction and provide data reference for the improvement of logistics information system.

Third, the design of classroom teaching assessment and evaluation system. Teaching evaluation assessment is an important content of classroom teaching, which can determine whether the teaching mode adopted is efficient and whether the talent team cultivated meets the needs of market development. Therefore, under the background of project-oriented and task-driven teaching model reform and innovation, the traditional classroom teaching assessment system cannot achieve an effective evaluation of teaching model and teaching quality. In order to implement a new teaching model, it must be able to set up a new teaching evaluation system. Currently, incentives can be used to add points, and students with the highest incentive scores will be given priority for job recommendation opportunities. In the process of bonus points and incentives, it can help students better pursue the in-depth practical knowledge of Logistics Strategy Consulting. Multi-subject evaluation methods can also be used to effectively improve and cultivate students' teamwork ability and spirit of cooperation. What's more important is to abandon the traditional single assessment method with the final exam as the main, and to incorporate the various forms of assessment mentioned above. Only in this way can it is possible to ensure the effective development of the new teaching model.

\section{Conclusion}

In summary, under the project-oriented, task-driven teaching mode, the course Logistics Strategy Consulting realizes innovative changes. In the teaching goals, more and more attention is paid to the cultivation of students' practical application ability, and students are required to better adapt to the professional requirements of future market logistics positions and to better serve future jobs. In the design of the teaching organization form, it is required to pay attention to the use of step-by-step teaching methods, and to gradually improve the operation ability of students by constructing a stepped skill training model. It is also required to be able to adopt diversified teaching methods to better attract students' interest in learning, complete the establishment of a new course assessment system, and achieve multiple evaluations, multi-subject evaluations and multiple evaluations. This effectively improves the teaching efficiency and teaching quality of the Logistics Strategy Consulting course.

\section{References}

1. Yu S. The design and implementation of the action-oriented "project-led, task-driven" teaching model. Fujian Transportation Science and Technology 2020; (03): 184-186.

2. Zhang H. Based on the "project-oriented, task-driven" teaching model design and implementation-Take the course Convention and Exhibition Marketing as an example. Knowledge Economy 2018; (10): 120-121.

3. Luo G. Teaching reform practice based on the project-task-driven Java Web Programming course. Contemporary Educational Practice and Teaching Research 2019; 22: 195-196+229.

4. Lv L. Research on the application of project teaching method in higher vocational computer course teaching [dissertation]. Shandong Normal University; 2018. 